\title{
CANADIAN JOURNAL OF
}

\section{Disability Studies}

Canadian Journal of Disability Studies

Published by the Canadian Disability Studies Association Association Canadienne des Études sur le Handicap

Hosted by The University of Waterloo

www.cjds.uwaterloo.ca

cjdseditor@uwaterloo.ca

This document has been made accessible and PDF/UA compliant by Accessibil-IT Inc.

For more information go to

http://www.accessibilit.com

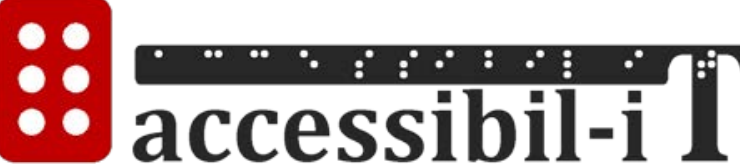




\title{
James Berger (2014). The Disarticulate: Language, Disability, and the Narratives of Modernity. New York: New York University Press. ISBN 978-0-8147-2530-6.
}

\author{
Reviewed by Jennifer Janechek \\ English Department, University of Iowa \\ jennifer-yirinic@uiowa.edu
}

"[D]isability theory seems marked by an inability to mourn while trauma theory suffers from an inability to stop mourning" (11). With this powerful assertion, James Berger launches his critique of the disjuncture between disability studies and trauma studies in The Disarticulate: Language, Disability, and the Narratives of Modernity, a work that explores figurations of "dys/disarticulation," or failures of articulation that result in exclusion from the social-symbolic order, in modernist literature. For Berger, the seeming incommensurability between the two fields results from trauma theory's inattention to specific instances of oppression and disability theory's resistance to "think[] the negative," its reluctance to acknowledge that pain, trauma, loss, impairment, and care can be integral components of a disability theory that more thoroughly challenges normative ideologies (160). As he provocatively—but, I think, rightly—argues, because disability studies tends to conceptualize trauma only as the structural damage done to the norm by the presence of alterity, redirecting attention away from the "event" of, and the suffering caused by, impairment, it "has constructed a picture of a rigid disability subjectivity that is a parodic echo of the normative subject it creates" (174). The Disarticulate challenges readers to consider a way out of this aesthetic and ethical impasse - to imagine a disability subjectivity resistant to totalizing perspectives, both those offered by normative ideologies and disability studies itself. According to Berger, such a confrontation between aesthetics and ethics does not resolve itself in the sublime, as Ato Quayson (2007) suggests in Aesthetic Nervousness, but in the dys-/disarticulate, the figure of linguistic and/or cognitive impairment situated at the 
border of the linguistic and the non-linguistic, the social-symbolic order and the unsymbolizable real. Attending to tropes of linguistic impairment, he suggests, reveals how modernist authors responded to the assimilatory forces of modernity with an ethics of care that affirms humankind's essential vulnerability and its constitutive alterity—its otherness from itself-and thus its need for interdependence.

Berger's theory of dys-/disarticulation relies on an appreciation of metaphor's power to resist "terroristic" (or its double, "transcendent") claims of singleness of meaning, hence his interest in literary works that seek access, through the figure of linguistic impairment, to nonlinguistic, unassimilable realms such as those occupied by divinity, the real, the unconscious, etc. He determines that the dys-/disarticulate character functions metaphorically as an other to symbolization and the dominant discursive forces at work on modern subjects: his or her linguistic impairment destabilizes the social-symbolic order, creating textual ripples of dys/disarticulated prose, while also serving as a point of intersection for attitudes and anxieties regarding not only cognitive and linguistic difference, but also current discourses in theology, politics, semantics, ethics, science, and aesthetics. An outsider of language but represented in language, the dys-/disarticulate carries some of the revolutionary power of the non-linguistic real into the symbolic, but as a representation of an individual situated in political, economic, and social circumstances, he or she demands both ethical and aesthetic consideration.

Consequently, Berger takes aim at disability studies' longstanding critiques of disability metaphor. While acknowledging the validity of the rationale behind criticisms of disability as trope - namely, its usual distance from the lived reality of disability and the issues of representational ownership it presents - he recommends viewing metaphor not as substitution but as catachresis, "a creative and maieutic... act [that] brings something new into the world" by 
reconfiguring language to "denote some entity that has not yet been adequately conceptualized and that has, at present, no word that signifies it" (149). After all, Berger insightfully points out, it is fallacious to imagine that there is a "true term" of disability that exists when figurative language is stripped away; such a perspective assumes that there is no "residue" of signification and, in fact, engages in the same totalizing rationale that constructs alterity as deviance (149). To that end, he praises the work of disability scholars such as Robert McRuer, Michael Davidson, Tobin Siebers, and Tom Shakespeare for identifying the subversive and liberatory potential of metaphorical representations of disability and for re-integrating the notions of impairment and pain back into discussions of disability-as-identity politics - a path paved by thinkers like Martha Nussbaum and Eva Kittay in their theorizations of a subjectivity constructed through interdependence, care, and compassion. The Disarticulate serves as an important intervention into disability studies work that, in its focus on disability rights advocacy, might end up bolstering the hegemony of normalcy through its overvaluation of autonomy, its unwillingness to admit or take advantage of the messiness of language, and its neglect of issues crucial to those with cognitive disabilities.

The majority of the argument cited above is found in Berger's fourth chapter, which is quite helpful in its assessment of "canonical" disability studies work and in its potential to overhaul conversations about dependence. However, while his critique of early disability studies work is fair, more recent scholarship such as that by Alison Kafer, who in Feminist, Queer, Crip (2013) acknowledges that the desire for medical intervention or curative measures might exist among some people with disabilities but this should not detract from their wish to be valued as a minority identity, presents the sort of nuanced readings of disability, impairment, and care that Berger finds lacking. In addition, more often than not, the writers whom Berger criticizes have, 
since the publication of their seminal disability studies texts, revised or complicated their positions. For instance, he questions Lennard J. Davis's argument in Enforcing Normalcy (1995) that the function of nineteenth- and twentieth-century novels is to police and assimilate physical and mental difference - though I think Berger's own analyses in Chapter 2 demonstrate that this sort of oversight is often a characteristic of modern novels with their eugenic and systematizing impulses and might even, in my reading/extension of his argument, distinguish modern texts from postmodern ones — but gives only a passing mention to Davis's concept of "dismodernism" developed in Bending over Backwards (2002) and elaborated in The End of Normal (2014). According to Davis, dismodernism acknowledges the universalism, cosmopolitanism, dependency, interdependency, and incompleteness of the subject and invites an understanding of disability as "the postmodern subject position" (2002, p. 14). Similar to Berger's perspective on the dys-/disarticulate, then, dismodernism reveals how disability can function as "a position of critique and potential liberation," uncovering the various oppressions humans face because of the regulatory and totalizing discourses of modernity (153). All of that to say, I think dys/disarticulation is a very useful concept that will greatly benefit the field, but its concerns and applications are not terribly discordant with much contemporary disability studies scholarship.

Because Berger's nuanced readings of dys-/disarticulation in modernist texts are so valuable, I think that a more direct treatment of linguistic impairment in his reformulation of disability studies would also have been very beneficial. In this crucial fourth chapter, which feels very separate from the preceding ones, the only literary analyses are of Sophocles' Philoctetes, Philip Roth's The Ghost Writer, and Herman Melville's Moby Dick—analyses that do not pertain to linguistic impairment: even though Philoctetes can be considered "dys-/disarticulated" in his expulsion from the social-symbolic realm and his proto-linguistic voicings, his impairment is 
rooted in his snake-bitten foot; Melville's Ahab similarly has a mobility impediment; and Roth is used not for a connection to disability but to show the problems of reductive attitudes toward metaphor. By the end of the chapter, we have seemingly strayed far from the catachrestic linguistic other so crucial to Berger's formulation of alternative discourses of human relations. If the dys-/disarticulate is to link the fields of trauma studies and disability studies as he suggests, it seems crucial to attend more directly to representations of communicative disorders and cognitive and physical disabilities that affect language use.

Nevertheless, in his readings of works by William Faulkner, Joseph Conrad, Djuna Barnes, Paul Auster, Jerzy Kosinski, Don DeLillo, Mark Haddon, Jonathan Lethem, and others, Berger effectively resituates modernism's fascination with linguistic experimentation in the scientific, political, and aesthetic discourses related to "degeneracy" and "feeble-mindedness," showing the centrality of conceptions of disability to literary modernism. In addition, he provides a comprehensive reformulation of Western philosophies of language and subjectivity in light of disability studies - an attempt that is surely so painstaking, so demanding in its negotiations between theorists such as Barthes, Bataille, Derrida, Lacan, and Levinas, to name only a few, that it almost necessitates the loose ends and lingering questions left in the book's wake. One of the most pressing of these questions is found in the final chapter, which, distinguishing between neuroscience-in-practice and neuroscience-in-ideology, submits that the former recasts cognitive and linguistic impairment as existing on a neurological spectrum that allows for "revised articulations" of alterity and "new forms of care" - care that now becomes a "constitutive feature of biological and social life" $(230,185)$. This nagging question is how, given Berger's claims about neuroscience's ability to re-articulate forms of linguistic and cognitive otherness within a neurological spectrum that prevents the dys-/disarticulate from being conceivable outside the 
social-symbolic order, is there any room left for alterity? Is not the author, in his faith in neuroscience's exhaustive cataloguing and containment of individual difference, accepting a totalizing ideology that he elsewhere disavows? If so, what room is left for the linguistic and aesthetic experimentation fostered by dys-/disarticulation? If nothing exists outside of the discourse of neuroscience, what can the catachrestic dys-/disarticulate character carry into language? These questions, among others, merit further consideration. Surely Berger's profound and challenging study has done the hard work of developing a methodology for approaching a metaphorics of linguistic impairment through the lens of structuralist, poststructuralist, and psychoanalytic theories of subjectivity, language, and desire. In reconsidering such theories in light of disability studies scholarship, The Disarticulate greatly benefits not only disability studies and literary studies but the disciplines of philosophy, history, political science, and linguistics by formulating an ethics of interdependence grounded in articulations and rearticulations of recognition and misrecognition of otherness.

\section{References}

Davis, L. J. (1995). Enforcing Normalcy: Disability, Deafness, and the Body. London: Verso.

Davis, L. J. (2002). Bending Over Backwards: Disability, Dismodernism and Other Difficult Positions. New York: New York University Press.

Davis, L. J. (2014). The End of Normal: Identity in a Biocultural Era. Ann Arbor: University of Michigan Press.

Kafer, A. (2013). Feminist, Queer, Crip. Bloomington: Indiana University Press.

Quayson, A. (2007). Aesthetic Nervousness: Disability and the Crisis of Representation. New York: Columbia University Press. 